\title{
Evaluation of Regeneration and Apoptosis in Experimental Hepatic Resection of Rats
}

\section{Deneysel Karaciğer Rezeksiyonu Olușturulmuş Ratlarda Rejenerasyon ve Apoptozun Değerlendirilmesi}

\author{
Şamil Öztürk ${ }^{1 *}$, Latife Ceyda İrkin ${ }^{2}$ \\ ${ }^{1}$ Çanakkale Onsekiz Mart University, Vocational School of Health Care Services, Çanakkale, Türkiye. \\ ${ }^{2}$ Çanakkale Onsekiz Mart University, Faculty of Applied Science,Çanakkkale, Türkiye. \\ e-mail: samilozturk16@hotmail.com, latifeirkin@gmail.com. \\ ORCID: 0000-0002-9435-8139 \\ ORCID: 0000-0001-6603-8413 \\ *Sorumlu yazar/ Corresponding Author: Şamil Öztürk \\ Gönderim Tarihi / Received: 24.02.2021 \\ Kabul Tarihi / Accepted: 31.05.2021 \\ DOI: $10.34087 /$ cbusbed. 886083
}

Giriş ve Amaç: Karaciğer rezeksiyonundan ve transplantasyondan hemen sonra apoptozis ve buna eşlik eden rejenerasyon başlar. DNA sentezinin ise rezeksiyondan sonra ilk 24-48 saatte maksimum düzeye ulaştığ1 bilinmektedir. $\mathrm{Bu}$ çalışma \%70 karaciğer rezeksiyonu uygulanan ratların karaciğerinde 3 ve 7 . günlerde ki rejenerasyonu ve apoptotik süreci incelemek üzere gerçekleştirildi.

Gereç ve Yöntemler: Wistar Albino cinsi erişkin 21 adet erkek siçan kullanıldı. Karaciğer rezeksiyonu oluşturmak için deneklere üst orta hat insizyon ile laparotomi uygulandı. Kontrol (Grup I), rezeksiyondan 3 gün sonra sakrifiye edilen grup (Grup II) ve rezeksiyondan 7 gün sonra sakrifiye edilen grup (Grup III) olacak şekilde toplam 3 grup oluşturuldu.

Bulgular: Kontrol grubu dışında tüm deney gruplarının karaciğer dokularında sinüzoidal dilatasyon ve hepatositlerde vakuolizasyon görüldü. Ancak, bu histopatolojik bulguların 2. grupta diğer gruplardan daha fazla olduğu gözlemlendi. Apoptotik indeks ve proliferasyon indeks değerlerinin 2. grupta maksimum seviyeye ulaştığı görüldü. 3. grupta ise bu indeks değerlerinin giderek azaldığı görülmüştür. Kontrol grubunda bu parametrelere ait değerler oldukça düşük değerlerde bulunmuştur.

Sonuç: Sonuç olarak, rezeksiyon sonrası meydana gelen rejenerasyona eşlik eden mekanizmaların günlere göre karşılaştırılmaları immünohistokimyasal ve TUNEL metodlarıyla tespit edilmiş olup klinik uygulamalara 1şık tutacak bulgular elde edilmiştir.

Anahtar kelimeler: Apoptozis, Hepatik rezeksiyon, Proliferatif nükleer antijen, Rejenerasyon.

\section{Abstract}

Objective: Apoptosis and accompanying regeneration begins immediately after liver resection and transpalantation. It is known that DNA synthesis reaches its maximum level in the first 24-48 hours after resection. This study was carried out to examine the regeneration and apoptotic process in the liver of rats that underwent $70 \%$ liver resection on days 3 and 7.

Materials and Methods: 21 adult male Wistar Albino rats were used. The laparotomy with an upper midline incision was performed on the subjects for liver resection. Three groups were formed as the control (Group I), the group that was sacrificed 3 days after resection (Group II), and the group that was sacrificed 7 days after resection (Group III).

Results: Sinusoidal dilatation and vacuolization in hepatocytes were observed in the liver tissues of all experimental groups except the control group. However, these histopathological findings were observed more in group II than other groups. It was observed that the apoptotic index and proliferation index values reached the maximum level in the group II. In group III, it was observed that these index values gradually decreased. Values of these parameters were found to be quite low in control group. 
Conclusion: As a result, comparisons of the mechanisms accompanying the regeneration occurring after resection were determined by immunohistochemical and TUNEL methods, and findings that shed light on clinical applications were obtained day by day.

Keywords: Apoptosis, Hepatic resection, Proliferative nuclear antigen, Regeneration.

\begin{tabular}{ll}
\hline 1. Introduction & stimulus with TUNEL and PCNA on the 3rd and 7th \\
The liver is an important organ of circulatory system to & days.
\end{tabular}
metabolize and store nutrients from the intestines [1]. The liver has many metabolic and vital functions as metabolism of digested proteins, carbohydrates and lipids. Many different metabolic, toxic, microbial, circulatory and neoplastic diseases affect the liver. In some cases, the disease occurs primarily in the liver, while in diseases such as heart failure, common cancer, extrahepatic infections and alcoholism, the liver is damaged secondaryly. When the liver is damaged due to various reasons, replication and proliferation may begin to complete its functional mass [2,3]. This feature is extremely important for hepatocytes that normally divide rarely. The liver has an enormous intercellular interaction and a complex mediator network that can repair itself within a few weeks in cases of significant tissue loss, and tissue regeneration occurs rapidly after resection [4].

It is one of the most important steps in modern surgery that liver regeneration has become a common and controllable procedure. For cancer treatment or transplantation, $60-70 \%$ of the liver volume can be safely removed to be used as a liver donor graft [5]. Today, in studies conducted with methods such as computed tomography, angiography and scintigraphy, it has been shown that the liver reaches its original size in 3-6 months in adults and in less than 3 months in children after liver resection. In the presence of cirrhosis, this period is up to $9-15$ months [6]. It has been reported that the human liver can tolerate even resections up to $80-85 \%$ [7]. Regeneration occurs even if the resection is less than $10 \%$ [8]. Hepatocytes normally show very rare mitosis activity. However, active cell replication begins within 24 hours after partial hepatectomy and continues until the organ reaches its normal weight. Significant regeneration occurs within the first 10 days and this event is completed in 4-5 weeks [9]. Regeneration mostly occurs in the form of new lobules and the growth of residual lobules. Endocrine, paracrine, and autocrine interactions are required for regeneration and liver remodeling after partial hepatectomy experimentally in humans and animals [10].

It has been observed that hepatocyte proliferation increases in cases such as surgical removal of a part of the liver lobes or damage to hepatocytes from viruses or chemicals. Various drug administrations are also used for faster recovery of the medically damaged liver $[11,12]$. However, as with many chemical drug treatments, side effects are inevitable in these studies. Therefore, in this study, we aimed to demonstrate the apoptosis and accompanying regeneration occurring in the liver tissue as a result of hepatectomy without any

\section{Materials ve Methods}

In this study, 21 adult male Wistar Albino rats weighing between 250-300g were used. During the duration of the experiment, all subjects were fed with daily water and pelleted feed containing $21 \%$ crude protein under optimum laboratory conditions $\left(22 \pm 1^{\circ} \mathrm{C}, 12\right.$ hours light/dark cycle). A total of 3 groups were formed in the experiment.

Group I: (Control group) No treatment was performed on the rats in this group,

Group II: The group of liver tissues for examination 3 days after resection,

Group III: The group liver tissues were taken for examination after 7 days from resection.

Approval for the study was obtained from Trakya University Ethics Committee on 09.06.2011.

2.1.Hepatic resection method

Ketamine (Ketalar ${ }^{\circledR}, 10 \mathrm{ml}, 50 \mathrm{mg} / \mathrm{ml}$, Pfizer, USA) $(25 \mathrm{mg} / \mathrm{kg}$, intramuscular) $50 \mathrm{mg} / \mathrm{kg} / \mathrm{ip}$, xylazine (Rompun ${ }^{\circledR} 50 \mathrm{ml}, 23,32 \mathrm{mg} / \mathrm{ml}$, Bayer, Germany) $5 \mathrm{mg} / \mathrm{kg} / \mathrm{General}$ anesthesia was applied with a rope. Laparotomy was performed with an upper midline incision. The left lateral and median lobe pedicles of the liver were tied with $4 / 0$ silk and $70 \%$ hepatectomy was performed as defined by Higgins and Anderson [13]. After the surgical procedure, the fascia was closed with $3 / 0$ vicryl and the skin with 4/0 silk and cleaned with povidone iodine. Oral intake of water and diet was allowed from the 24th post-operative hour [14].

\subsection{Histopathological parameters}

The liver tissues were fixed in Bouin fixator for 24 hours, and then tissues were washed in $70 \%$ alcohol for 2 days and the dehydration process was started. Tissues were kept for 1 hour in increasing alcohol series (70$100 \%$ ). Before embedding, the tissues were kept in soft paraffin for 1 night. The next day, liver tissues were removed from soft paraffin and kept in liquid hard paraffin for 1 hour and blocked. $5 \mu \mathrm{m}$ thick sections were taken from these blocks using a Leica RM-2245 cylinder microtome. The sections taken were stained with $\mathrm{H} \& \mathrm{E}$.

\subsection{Immunohistochemistry}

The sections lowered into water were boiled for 20 minutes in the microwave oven in antigen retrival. After the sections were washed with PBS. After this step, it was treated with $3 \%$ hydrogen peroxide $\left(\mathrm{H}_{2} \mathrm{O}_{2}\right)$ prepared in methanol (Riedel-de Häen 24229) for 20 minutes to remove the hydrogen peroxidase activity. $1 \%$ Preimmune rabbit serum (Ultra V Block, LabVision, TA-015-UB) was applied to sections to block non-specific antibody binding. The sections were then incubated with primary antibody diluted $1 / 100$ in 
the moist chamber for 1 hour. The antibody used was mouse monoclonal anti-PCNA antibody (MS-106-B, Thermo LabVision, USA). Sections were kept in secondary antibody solution (Biotinylated Goat AntiMouse, LabVision, TM-015-BN) for 20 minutes after washing with PBS three times. Streptavidin peroxidase solution (Streptavidin Peroxidase, LabVision, TS-015HR) was applied to the sections. After washing the sections three times with PBS, 3-amino 9 ethyl carbazole (AEC) chromogen solution (LabVision, TA002-HAC) was applied for ten minutes.

\subsection{Proliferation index}

After fixing in Bouin fixator for four days, tissue was blocked in paraffin after routine tissue follow-up and stained with proliferated cell nuclear antigen (PCNA) from immunohistochemical stains. Proliferation index; PCNA stained cell number and total hepatocyte count at 30 high power fields were calculated. It was then defined as the ratio per 1000 cells [15].

Proliferation index $=$ (number of PCNA stained cells) / (total number of cells) $\times 100$

\subsection{Apoptotic index}

After fixing in Bouin fixator for 4 days, liver tissue was blocked in paraffin after routine tissue follow-up and stained with TUNEL kit, which is an apoptosis marker. Apoptotic index; TUNEL stained cell count and total hepatocyte count were calculated in 30 large magnification fields. It was then defined as the ratio of every 1000 cells [15].

Apoptotic index $=($ apoptotic cell number $) /($ total cell number) $\times 100$

\subsection{Statistical analysis}

All data were expressed as mean $( \pm)$ standard deviation (SD). The differences in the results between the groups were evaluated by Kruskal-Wallis analysis of variance. For comparisons between groups with significant differences, Mann-Whitney U test was used. If $\mathrm{p}<0.05$, the difference was considered statistically significant. In addition, hepatocyte vacuolization and sinusoidal dilatation numbers were determined semiquantitatively in all groups. Semi-quantitative evaluation was as follows; none $(-)$, rare $( \pm)$, low $(+)$, medium $(++)$, too much $(+++)$, too much $(++++)$.

\subsection{TUNEL assay}

Table 1. Semi-quantitative evaluation of hepatocyte vacuolization and sinusoidal dilatation in experimental groups

\begin{tabular}{|l|c|c|c|}
\hline Groups & $\begin{array}{c}\text { Group I } \\
\text { (control) }\end{array}$ & $\begin{array}{c}\text { Group II (3th } \\
\text { day) }\end{array}$ & Group III (7th day) \\
\hline Hepatocyte vacuolization & - & +++ & ++ \\
\hline Sinusoidal dilatation & - & ++ & + \\
\hline
\end{tabular}

\subsubsection{Immunohistochemical findings}

PCNA values found in all groups were compared. Significant difference was found between the control and the other groups in all periods statistically. PI value of the group I, group II and group III were determined. The statistically significant difference between the
The $5 \mu \mathrm{m}$ sections taken from the paraffin blocks on the slide were kept in an oven at $37^{\circ} \mathrm{C}$ for 24 hour, then kept in toluol for $3 \times 5$ minutes and then passed through the decreasing alcohol series $(100 \%, 95 \%, 70 \%)$ for 3 minutes and lowered into distilled water. Proteinase $\mathrm{K}$ (20 $\mu \mathrm{g} / \mathrm{ml}$, Chemicon, 21627) was applied to the sections kept in distilled water for five minutes at room temperature for fifteen minutes for antigen recovery. After shaking with distilled water and pool was created for five minutes at room temperature with equilibration buffer. Then the sections were kept at $37^{\circ} \mathrm{C}$ in $\mathrm{TdT}$ enzyme for an hour, then rinsed with stop/wash buffer for fifteen second and kept at room temperature for ten minutes. Conjugate of antidigoxigenin was applied to sections washed in PBS three times and kept at room temperature for thirty minutes. After washing the sections three times with $\mathrm{PBS}$, diamino benzidine (DAB) chromogen solution (LabVision, TA-002HAC) was applied for ten minutes and closed with coverslip and evaluated under a light microscope.

\section{Results and Discussion}

3.1.Results

3.1.1. Light microscopic findings

When H\&E stained liver sections of rats in the control group were examined, it was observed that liver sections were in normal histological appearance. Hepatocyte nuclei are large and round in shape, and their cytoplasm stained with eosinophilia.

Hepatocyte vacuolization and sinusoidal dilatation counts were determined semi-quantitatively in all groups. It has been observed that hepatocytes in liver sections belonging to group II and group III are common in hepatocytes at various stages, vacuolization and sinusoidal dilatation in hepatocytes has been noted. Hepatocyte vacuolization (+++) and dilatation were determined as moderate (++) in the group II. In the sections belonging to group III, it was determined that hepatocyte vacuolization decreased in medium $(++)$ and sinusoidal dilatation decreased as little $(+)$. When the sections belonging to all groups were evaluated, the classical liver lobule structure was preserved (Figure 1, Table 1). 

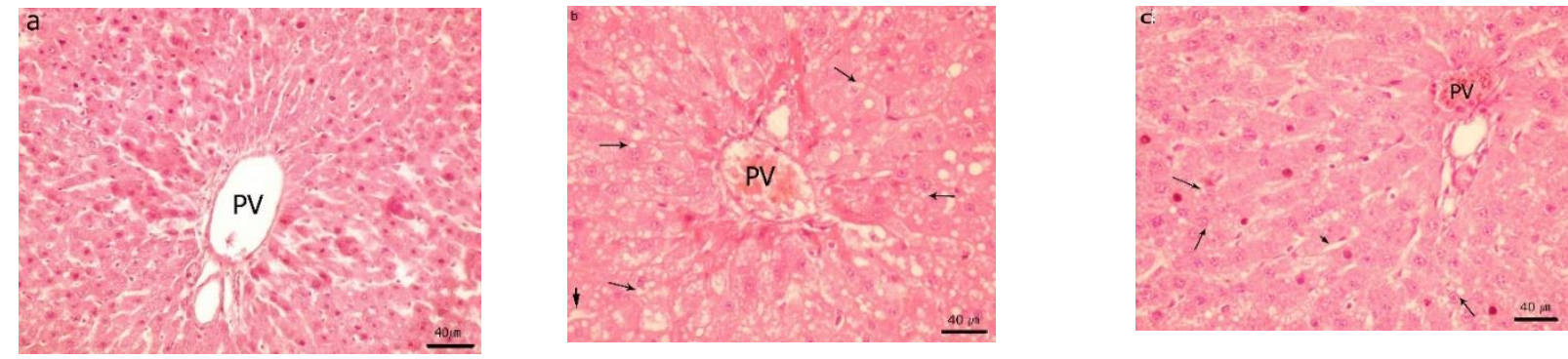

Figure 1. a) Group I (control), normal histological appearance of the liver, b) the liver section after 3 day of resection-intense vacuolization is seen around the portal areas (Group II), c) the liver section after 7 day of resection-vacuolization is seen around the portal areas (Group III) (X400), H\&E.
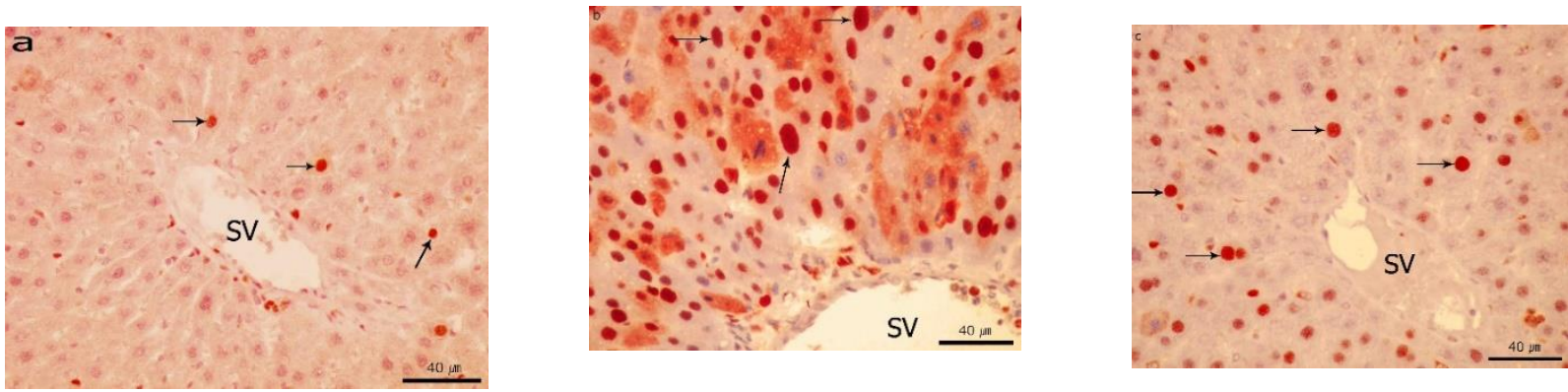

Figure 2. a) PCNA immunostaining of Group I (control) liver section, b) PCNA immunostaining of the Group II (3 day after resection)-PCNA positive cell density is seen, c) PCNA immunostaining of the Group III (7 days after resection)-PCNA positive cell density is seen, hematoxylin counterstaining (X400).

\subsubsection{TUNNEL findings}

A statistically significant difference was found between the control (I) and other groups (II, III) in all three periods when the apoptotic index values obtained as a result of the evaluation of cells whose apoptotic nuclei were stained as a result of TUNEL staining performed on all groups. The statistically significant difference between the groups was evaluated according to $p<0.05$. When the group I and II were compared, a statistically significant difference of $\mathrm{p}<0.001$ was determined. When the group III and control group were compared, statistically $\mathrm{p}<0.01$ was determined (Figure 3, Figure $4)$.
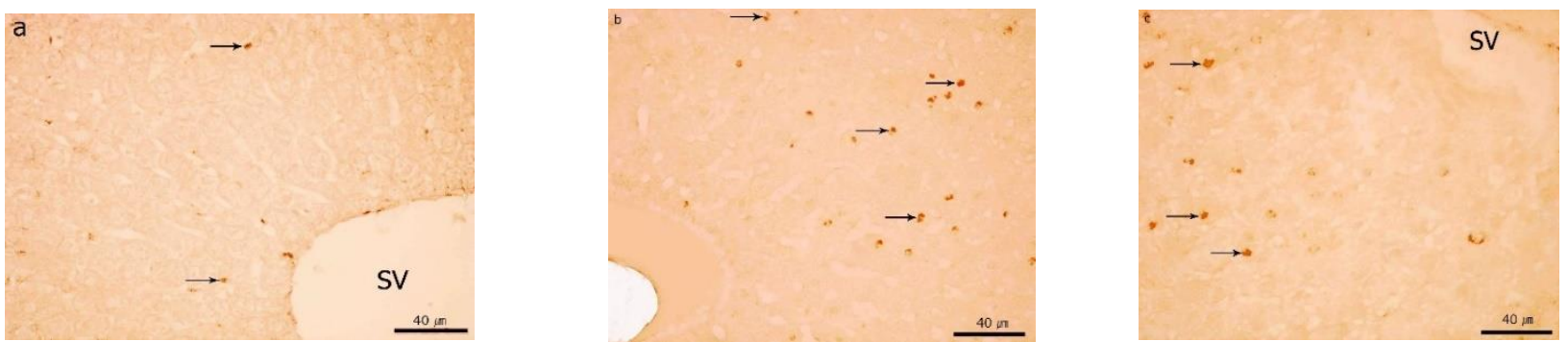

Figure 3. a) The liver section of Group I (control), b) Group II (3 day after resection)-TUNEL positive cell high density was seen, c) Group III (7 days after resection)-TUNEL positive cell low density was seen (X400), TUNEL staining.

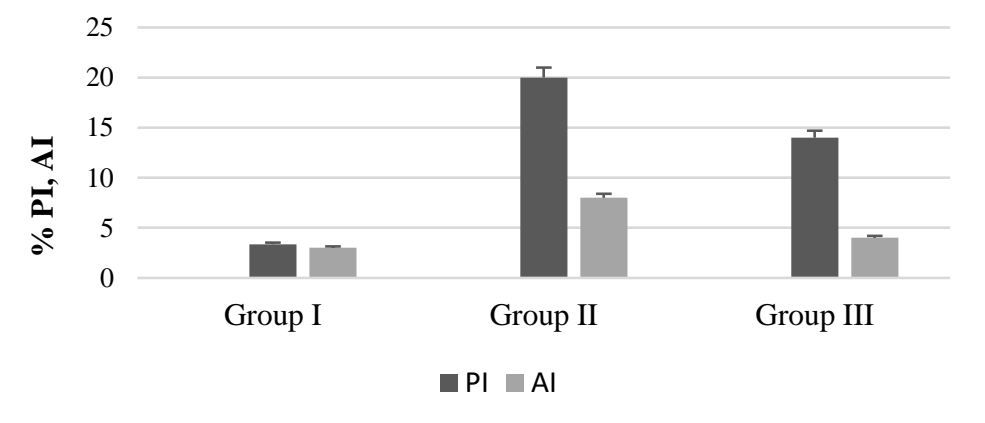

Figure 4. Proliferative and Apoptotic index values of control and experimantal groups. 


\subsection{Discussion}

Liver has important and vital functions involving all systems of the body, containing the mystery of many basic mechanisms such as biotransformation, regulation of metabolic functions, and immunological events that have not been fully and clearly resolved [16, 17].

Partial hepatectomy is a commonly performed surgical procedure and an inevitable treatment option for primary liver tumors, trauma, liver metastases of gastrointestinal tumors, and liver transplantation [18]. Liver resection has become safer, especially in the last twenty-five years, with the development of diagnostic methods, improvement and improvement in surgical techniques, and improvement in postoperative care [19]. Postoperative mortality and morbidity in liver resection are directly related to preoperative liver function and the regenerative capacity of the remaining liver after postoperative resection. It is a very important support mechanism for replacing the functional hepatic mass in a short time after regeneration of liver tissue with normal parenchyma, tissue injuries and hepatocellular necrosis. Active cell replication begins within 24 hours after partial hepatectomy, and this replication continues until the organ reaches its first weight [8].

The regulatory mechanisms in liver regeneration, the changes that occur and their interrelationships are not known exactly. But liver knows when to start and stop the [20]. Loss of liver tissue initiates regeneration [21]. The sensitive point that allows regeneration to stop is the relationship between body mass and liver mass. When the liver reaches the size to meet the functional needs of the body and carry out metabolism, regeneration stops [22-24]. When a large liver tissue transplant is performed after transplantation relative to the recipient, liver mass decreases until the optimal liver to body mass ratio [25].

Liver regeneration rates can be calculated by evaluating the liver mass taken in damages caused by partial hepatectomy and the masses of the whole liver taken after a certain time after hepatectomy. They reported that the remaining liver weight doubled 48 hours after $2 / 3$ partial hepatectomy in rats and reached full weight within 7-10 days. In our study, it was found that the liver weights regenerated after 72 hours after partial hepatectomy nearly doubled in the partial hepatectomy groups [26, 27].

Determination of the proliferation index (PCNA index) has been used frequently on liver regeneration and has played an important role in the interpretation of regeneration [28-32]. Hou et al. Mitotic index and PCNA index were also used to determine the effects of an organic compound named FR167653 on liver regeneration in rats with partial hepatectomy [25]. In their study, they determined that the mitotic index they determined simultaneously from the liver sections of the control group rats they underwent partial hepatectomy was higher than the PCNA index. The
PCNA index in this study are in parallel with these results of the research. PCNA index results was high in group II and III in this study PCNA indexes were found higher on the 3rd day than the 7th day. When the PCNA index results were evaluated in this study, they were parallel to the previous studies. Proliferation index values between the groups were found to be statistically significant.

Akcan reported that one of the opposite mechanisms seen after hepatectomy is apoptosis and that cell apoptosis begins when regeneration reaches its peak [33]. It also showed that apoptosis accompanies cell proliferation, overgrown cells are eliminated and new tissue formation is successfully completed. Sowa JP et al. showed that the TUNEL index increased significantly after resection. Although apoptosis decreased over time, the TUNEL index continued to increase compared to control groups. Thus, these results showed that in $70 \%$ hepatectomy, apoptosis occurs first and regeneration accordingly. In addition, more tissue damage in the early postoperative phase indicates an increase in the number of apoptotic cells [34]. In contrast, a slight increase in the TUNEL index was seen at the beginning of $90 \%$ hepatectomy. However, 7 days after the operation, apoptosis was observed to increase strongly, which means that the damaged tissue regenerated after the significant increase in the TUNEL index after 7 days. In group II, apoptosis was high, and in the following days, it was observed that apoptosis gradually decreased in the group III.

\section{Conclusion}

In this study, it was observed that vacuolization of hepatocytes and dilatation in sinusoids occurred first after partial hepatectomy, and regeneration increased in parallel with this in the following days. In immunohistochemical staining of liver tissue, PCNA positive cells were found very high in group II and group III. It was observed that the number of positive cells in the group decreased. Apoptotic cells were observed as TUNEL positive in staining with TUNEL method. It was observed that the apoptotic index values increased after 72 hours. TUNEL positive cells were observed to decrease in group III. As a result, comparison of the mechanisms accompanying the regeneration occurring after resection by day has been presented.

\section{References}

1. Kumar, V, Cotran, R.S, Robbins, S.L (Çeviri: Cevikbaş, U). Robbins Temel Patoloji, Nobel Yayınları, 7. Baskı, İstanbul, 2003, 596-9.

2. Michalopoulos, G.K, Principles of liver regeneration and growth homeostasis, Comprehensive Physiology, 2013, 3(1), 485-513.

3. Ishikawa, J, Takeo, M, Iwadate, A, Koya, J, Kihira, M, Oshima, M, et al., Mechanical homeostasis of liver sinusoid is involved in the initiation and termination of liver regeneration, Communications Biology, 2021, 4(1), 409.

4. Liu, Y, Shi, C, Cui, M, Yang, Z, Gan, D, Wang, Y, Different doses of partial liver irradiation promotes hepatic regeneration in rat, International Journal of Clinical and Experimental Pathology, 
2015, 1, 8(6), 6554-9.

5. Duclos, J, Bhangui, P, Salloum, C, Andreani, P, Saliba, F, Ichai, et al., Ad Integrum Functional and Volumetric Recovery in Right Lobe Living Donors: Is It Really Complete 1 Year After Donor Hepatectomy?, American Journal of Transplantation, 2016, 16(1), 143-56.

6. Mizuno, S, Nakamura, T, HGF-MET cascade, a key target for inhibiting cancer metastasis: the impact of NK4 discovery on cancer biology and therapeutics, International Journal of Molecular Science, 2013, 14(1), 888-919.

7. Colle, I, Verhelst, X, Vanlander, A, Geerts, A, Van Vlierberghe, H, Berrevoet, F, Rogiers, X, et al., Pathophysiology and management of post resection liver failure, Acta Chirurgica Belgica, 2013, 113(3), 155-61.

8. George, M.K, Liver regeneration, Journal of Cellular Physiology, 2007, 213(2), 286-300.

9. Guo, Y.Y, Wu, Y, Jia, XW, An, W, Augmenter of liver regeneration potentiates doxorubicin anticancer efficacy by reducing the expression of $\mathrm{ABCB} 1$ and $\mathrm{ABCG} 2$ in hepatocellular carcinoma, Laboratory Investigation, 2017, 97(12), 1400-1411.

10. Zhang, G.Q, Zhang, Z.W, Lau, W.Y, Chen, X.P, Associating liver partition and portal vein ligation for staged hepatectomy (ALPPS): a new strategy to increase resectability in liver surgery, International Journal of Surgery, 2014, 12(5), 437-41.

11. Araújo, T.G, Oliveira, A.G, Franchi Teixeira, A.R, Low-Power Laser Irradiation (LPLI): A Clinical Point of View on a Promising Strategy to Improve Liver Regeneration, Journal of Lasers in Medical Sciences, 2018, 9(4), 223-227.

12. Andiran, F, Ayhan, A, Tanyel, F.C, Abbasoğlu, O, Sayek, I, Regenerative capacities of normal and cirrhotic livers following $70 \%$ hepatectomy in rats and the effect of alpha-tocopherol on cirrhotic regeneration, Journal of Surgical Research, 2000, 89(2), 184-8.

13. van Rosmalen, B.V, Bieze, M, Besselink, M.G, Tanis, P, Verheij, $\mathrm{J}$, Phoa, et al., Long-term outcomes of resection in patients with symptomatic benign liver tumours, Hepato-Pancreato-Biliary (HPB - Oxford), 2016, 18(11), 908-914.

14. Canbek, M, Uyanoglu, M, Canbek, S, Ceyhan, E, Ozen, A, Durmus, B. The effect of geraniol on liver regeneration after hepatectomy in rats, In Vivo, 2017, 31(2), 209-213.

15. Selzner, M, Clavien, P.A, Failure of regeneration of the steatotic rat liver: Disruption at two different levels in the regeneration pathway, Hepatology, 2000, 31, 35-42.

16. Akcan, A, The Effect of Amrinone on Liver Regeneration in Experimental hepatic resection model, Journal of Surgical Research, 2006, 130, 66-72.

17. Sowa, J.P, Best, J, Benko, T, Bockhorn, M, Gu, Y, Niehues, E.M, Extent of liver resection modulates the activation of transcription factors and the production of cytokines involved in liver regeneration, World Journal of Gastroenterology, 2008, 14(46), 7093-100.

18. Veteläinen, R, van Vliet, A.K, van Gulik, T.M, Severe steatosis increases hepatocellular injury and impairs liver regeneration in a rat model of partial hepatectomy, Annual Surgery, 2007, 245, 4450.

19. Meyers, W.C, Jones, R.S, Anatomy: In Meyers, W.C, Jones, R.S (eds), Textbook of liver and biliary surgery, Press: JB Lippincott Company, Philadelphia, 1990, 18-38.

20. Fausto, N, Liver regeneration, Journal of Hepatology, 2000, 32, 19-31.

21. Michalopoulos, G.K, DeFrances, M.C, Liver regeneration, Science, 1996, 296, 60-6.

22. Court, F.G, Wemyss-Holden, S.A, Dennison A.R, Maddern G.J, The mystery of liver regeneration, British Journal of Surgery, 2002, 89, 1089-95.

23. Kountouras, J, Boura, P, Lygidakis, NJ, Liver regeneration after hepatectomy, Hepatogastroenterology, 2001, 48(38), 556-62.

24. Michalopoulos G.K, Bhushan B, Liver regeneration: biological and pathological mechanisms and implications, Nature Reviews Gastroenterology \& Hepatology, 2021, 18(1), 40-55.

25. Hou, Z, Yanaga, K, Kamohara, Y, Eguchi, S, Tsutsumi, R, Furu, J, A new suppressive agent against interleukin- $1 \mathrm{~b}$ and tumor necrosis factor-a enhances liver regeneration after partial hepatectomy in rats, Hepatology Research, 2003, 26, 40- 46.

26. Tang, T.X, Hashimoto, T, Chao, L.Y, Itoh, K, Manabe, T, Effects of partial pancreatectomy on liver regeneration in rats, Journal of
Surgical Research, 1997, 72(1), 8-14.

27. Junqueira, L.C, Carneiro, J, Kelley, R.O, Basic histology, 10th Ed. Connecticut: Lange; 2002, 237-40.

28. Assy, N, Minuk, G.Y, Liver regeneration: methods for monitoring and their applications, Journal of Hepatology, 1997, 26, 945-52.

29. Sydor S, Gu Y, Schlattjan M, Bechmann L.P, Rauen U, Best J, Paul A, Baba H.A, Sowa J.P, Gerken G, Canbay A, Steatosis does not impair liver regeneration after partial hepatectomy, Lab Invest., 2013, 93(1), 20-30.

30. Castro-e-Silva, O, Zucoloto, S, Ramalho, FS, Ramalho, L.N.Z, Reis, J.M.C, Bastos, A.A.C, Brito, M.V.H, Antiproliferative Activity of copaifera duckei oleoresin on liver egeneration in rats, Phytotherapy Research, 2004, 18, 92-94.

31. Kamer, E, Çöker, A, Sevinç, A.R, Özkara, E, Özer, E, Özzeybek, $\mathrm{T}$, Effect of intraperitoneal dministration of gemcitabine and paclitaxel on hepatic regeneration in rats, Turkish Journal of Gastroenterology, 2003, 14(1), 1-6.

32. Veteläinen, R, van Vliet, A.K, van Gulik, T.M, Severe steatosis increases hepatocellular injury and impairs liver regeneration in a rat model of partial hepatectomy, Annual Surgery, 2007, 245, 4450 .

33. Kucuk C, Akcan A, Akyýldýz H, Akgun H, Muhtaroglu S, Sozuer E, Effects of amrinone in an experimental model of hepatic ischemia-reperfusion injury, J Surg Res., 2009, 151(1), 74-9.

34. Laurent S, Otsuka M, De Saeger C, Maiter D, Lambotte L, Horsmans Y, Expression of presumed specific early and late factors associated with liver regeneration in different rat surgical models, Laboratory Investigation, 2001, 81(9), 1299-307.

http://edergi.cbu.edu.tr/ojs/index.php/cbusbed isimli yazarın CBU-SBED başliklı eseri bu Creative Commons Alıntı-Gayriticari4.0 Uluslararası Lisansı ile lisanslanmıştır.

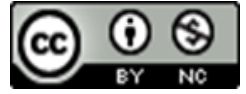

